\title{
Prudent Financial Management Practices among Malaysian Youth: The Moderating Roles of Financial Education
}

\author{
Mohd Zamri Abu BAKAR ${ }^{1}$, Saridan Abu BAKAR ${ }^{2}$ \\ Received: April 14, 2020 Revised: April 25, 2020 Accepted: May 07, 2020
}

\begin{abstract}
The study aims to investigate the roles of financial education (FE) as a moderator to financial attitude (FA), parental financial socialisation (PFS), and financial literacy (FL) to ensure the success of prudent financial management practices (PFMP) among Malaysian youth. The study was designed quantitatively and employed self-administered questionnaires, which were adopted from previous studies and distributed to 480 youths in Malaysia. The data were analyzed using Partial Least Squares Structural Equation Modeling (PLS-SEM) to test hypotheses of the study. The results showed FA, PFS and FL have significant and positive relationship with PFMP. However, as regards moderating interaction of FE, results showed that FE does not significantly moderate the relationship between FA, PFS and FL with PFMP. The results further highlighted serious concerns on the effectiveness of FE towards improving youth capability in managing their financial affairs prudently. This proved that mandated FE prior to graduation has less effect and does not lead to behavior changes among Malaysian youth. It shows the challenges faced by the country stakeholders to strengthen FE, enhance the effectiveness and encompass the right FE elements to ensure today's young Malaysians are able to apply what they learned in the classroom to their real life.
\end{abstract}

Keywords : Financial Education, Youth, Skills, Knowledge, Financial Behavior, Malaysia

JEL Classification Code: G4, G5, I3, M1, M5

\section{Introduction}

The sign of financial illiteracy could be clearly seen during the global financial crisis in 2007 and 2008, followed by the great recession that has brought world citizens into financial difficulties in managing personal finance affairs effectively because they failed to manage the risk taken and were incompetent to manage their money prudently (Zahirovic-Herbert, Gibler, \& Chatterjee, 2016). The impacts of the financial crisis have caused many individuals and households to be trapped in financial struggles; many of them have been diagnosed with depression and anxiety,

${ }^{1}$ First Author and Corresponding Author. Faculty of Business Administration, University Teknologi MARA, Malaysia [Postal Address: 40450 Shah Alam, Selangor, Malaysia] Email: zamrimfs@ yahoo.com

${ }^{2}$ Arshad Ayub Graduate Business School, University Teknologi MARA, Malaysia. Email: saridan@salam.uitm.edu.my

(c) Copyright: The Author(s)

This is an Open Access article distributed under the terms of the Creative Commons Attribution Non-Commercial License (http://Creativecommons.org/licenses/by-nc/4.0/) which permits unrestricted noncommercial use, distribution, and reproduction in any medium, provided the original work is properly cited. which in the worst case scenario can even lead to suicide (Kaplan, Huguet, Caetano, Giesbrecht, Kerr, \& McFarland, 2015). The assumptions are that all these financial constraints, such as high personal debt, low savings, inability to understand interest cost, poor budgeting and poor credit behaviors may have been alleviated if people have sufficient financial knowledge and skills that form the basis for dayto-day financial decisions. The impacts of the financial crisis have called policy experts, economists and government intervention in understanding and seeking the best solution to promote prudent financial behavior among citizens to create economic recoveries and physical financial stability of the country.

To close the gap between poor financial behavior and the importance of prudent financial management practices (PFMP), financial education (FE) has been introduced to reverse the trend and to ensure young people are able to manage their own financial affairs with sufficient knowledge and skills (Fan \& Chatterjee, 2019). Providing effective FE is critical to mitigate the issues in financial problems among the young generation and acknowledge it as the best platform to increase their financial knowledge and competence in money management throughout the individual's lifecycle. 
Financial information, knowledge gained and skills learned from either formal or informal $\mathrm{FE}$ will benefit them in terms of their application of theoretical knowledge because the lessons contained in FE will enhance their literacy, and are positively correlated with higher degrees of financial behavior and prudent financial practices. Hence, PFMP can be acknowledged as the best platform for the financial security of the youth, and can determine their present and future financial well-being by avoiding the risks of getting involved in financial difficulties including getting trapped with bankruptcy.

\section{Literature Review}

\subsection{Prudent Financial Management Practices (PFMP)}

PFMP refers to a process concerning the creation of value or wealth that requires effective financial decision (Titman, Keown, \& Martin, 2017). It is considered as formulation and implementation of money management that requires self-discipline. PFMP has also been conceptualised as selfreflecting that requires individuals to be cautious with their ability to consider the risks in the consequences of their actions, and to avoid an aggregation of certain losses (Wang $\& \mathrm{Li}, 2015)$. It can be considered as a degree of acceptance of vigilance or carefulness in practising decision when making estimates under conditions of uncertainty. It is a critical personal financial practice that requires individuals to make well-judged decision to ensure their expenditure does not exceed their income. To explain PFMP, a person is required to monitor closely his or her financial affairs, consider the options available, and before he or she makes any financial decisions, appreciate the consequences of the action to be taken (Mette, de Matos, Rohden, \& Ponchio, 2019). PFMP can become determinant factors in many aspects of individual financial life, which include children's education, participation in the market, wealth management, investment in insurance, retirement planning and future financial well-being (Messacar \& Frenette, 2019; Tham, Dastane, \& Johari, 2019). It helps ensure the person manages his or her available financial resources effectively to achieve financial goals in life, enjoy quality of life and constitute a stepping stone to financial independence.

Prudence in financial management is associated with healthy financial attitude and positive financial behavior because it facilitates a person to spend cautiously, understand financial choice and have self-control over his or her financial situation, particularly in decisions over savings, credit management or any day-to-day financial transactions (Aydin \& Akben, 2019). Consequently, PFMP plays critical roles and is of utmost importance for any individual in performing various financial activities because it is associated to the financial functioning of the individual's life and it affects many aspects of life. Understanding the factors influencing intentions towards PFMP is critical in determining individual financial behavior whether it is for the present or for the future (Ajzen, 1991). All the factors considered as critical success factors will help individual ease the route towards financial freedom and guaranteed financial well-being. The literature review indicates that financial attitude (FA), parental financial socialization (PFS), financial literacy (FL), and financial education (FE) have strong influence and are strong predictors of individual financial behavior (Guzman, Paswan, \& Tripathy, 2019; Potrich, Viera, \& Mendes-Da-Silva, 2016; Ramalho \& Forte, 2018). All these factors exert positive impacts on youth financial behavior, habit and practices. Moreover, the determinants work together closely and are interrelated. Surely, the construct predictors will influence behavior intentions among young people to apply the PFMP in their day-to-day routine financial life.

\subsection{Financial Attitude (FA)}

FA refers to disposition towards financial affairs (Ibrahim \& Alqaydi, 2013). Chowa and Despard (2014) defined FA as a person's state of mind, belief and assessment related to personal financial matters. It is related to the individual's belief and feeling about money, expressed by evaluating a particular entity with some degree of favour or disfavour that emerged and in behavioral responses (Eagly \& Chaiken, 2007). Paluri and Mehra (2016) conceptualised FA as a personal disposition towards financial affairs. It can be considered as combination of concepts, emotion and information related to learning that significantly influence a person to react favorably. FA is very important because it influences an individual's behavior intention in many aspects of financial affairs that include savings, borrowing, risk taking and adverse financial events (Skagerlund, Lind, Strömbäck, Tinghög, \& Västfjälla, 2018). Shim, Barber, Card, Xiao, and Serido (2009) also stressed the importance of FA in determining individual's financial well-being. Falahati and Paim (2012) stated that FA is a strong predictor of financial problems and a preventive measure from being trapped in financial problems. In this sense, understanding the factors that influence how youth manage their expenses in any financial activities remain important because they affect financial decisions and youth money practices or habits of youth. Since the youth are in the process of establishing a financial foundation and mostly likely be practising money management through trial and error, FA can become important predictors in determining youth behavior intention because the way they think and their perception will affect their financial behavior. Thus, the first hypothesis postulates a positive relationship between FA and PFMP as follows: 
$\mathbf{H}_{\mathbf{1}}$ : There is a positive and significant relationship between perceived Financial Attitude (FA) and Prudent Financial Management Practices (PFMP) among the Malaysian youth.

\subsection{Parental Financial Socialisation (PFS)}

PFS can be defined as a development process where children establish financial values, attitudes and behaviors that facilitate financial independence from their parents (Kagotho, Nabunya, Ssewamala, Mwangi, \& Njenga, 2017). Webley and Nyhus (2013) referred to PFS as a process where children are exposed to money management and they establish their own financial behavior, either incidentally or intentionally. It is a development stage where the individuals acquire and develop their own skills, perceptions and beliefs that influence them in the field of personal finance. These characteristics are acquired from their parents and will be used for the rest of their lives (Grohmann, Kouwenberg, \& Menkhoff, 2015). According to Gudmunson and Danes (2011), PFS is associated with the development of FA, financial capability and it is related to knowledge transfer. It is a process of establishing attitudes, standards, norms, knowledge and behaviors that enhances the financial wellbeing of an individual.

The roles played by parents have significant impacts over the course of the lives of young people and allow them to engage and practice money management skills independently. In fact, evidence has shown that the roles played by parents are not restricted only to the field of personal finance behavior, but also applicable to other fields such as consumer socialisation, electricity consumption, education, psychology and eating behaviors (AguirreBielschowsky, Lawson, Stephenson, \& Todd, 2018; Jung, 2019). PFS is considered as a lifelong process where individuals are constantly exposed to new financial patterns, experiences, social roles and situations throughout their lives by their parents. Although studies have revealed that children and young people learn and gain financial knowledge that shape their financial behavior mainly from various socialisation agents such as parents, peers, media, formal education, religion, work experiences, and the Internet, however, the majority of the studies have clearly emphasized that parents are the most influential primary socialisation agents (Mikeska, Harrison, \& Carlson, 2017; Zulfaris, Mustafa, Mahussin, Alam, \& Daud, 2020). Thus, the second hypothesis postulates a positive relationship between PFS and PFMP as follows:

$\mathbf{H}_{2}$ : There is a positive and significant relationship between perceived Parental Financial Socialisation (PFS) and Prudent Financial Management Practices (PFMP) among the Malaysian youth.

\subsection{Financial Literacy (FL)}

FL refers to the capability of a person to manage his or her own financial decisions according to skills and knowledge gained (Brown, Henchoz, \& Spycher, 2018). Luksander, Béres, Huzdik, and Németh (2014) defined FL as a person's knowledge in the field of finance, ability to process financial information, to make correct financial decisions and dealing efficiently with his or her own financial resources. Lusardi and Mitchel (2014) conceptualised FL as the ability of a person to process financial or economic information and to make informed decisions regarding his or her financial planning, wealth accumulation, pension and debt. It considered as the application of basic financial knowledge of compound interests within the context of financial decisions. The FL term goes far beyond financial knowledge because it represents understanding and application of knowledge rather than financial knowledge only, which represents the sole dimension of knowledge.

In other words, FE focuses on the process that is involved for the person to make financial decisions. While FL is about ability to make use of knowledge skills the person acquires or possesses. Thus, FL can refers to knowledge and understanding on money management, ability to apply knowledge gained and skills that a person has in making responsible economic decisions across a range of financial contexts to manage financial resources effectively for improving individuals' financial well-being. Poor FL level has affected many people across demographics and socioeconomic backgrounds to fall into financial difficulties due to making wrong financial decisions (Demirgüç-Kunt, Klapper, Singer, Ansar, \& Hess, 2018). People with poor FL may face adverse consequences of their financial decisions and, in the end, they become trapped in heavy debts and lose a lot of money. FL influences financial decisions and has a major impact in determining the financial behavior of individuals (Grohmann et al., 2015). Low FL makes people prone to financial mistakes, and improper financial decisions, whereas higher level of Thus, to be considered as financial literates, the person must have the know-how that encompasses the knowledge skills in personal finance and have the capability to understand, choose and decide. Thus, the third hypothesis postulates a positive relationship between FL and PFMP as follows:

$\mathbf{H}_{3}$ : There is a positive and significant relationship between perceived Financial Literacy (FL) and Prudent Financial Management Practices (PFMP) among the Malaysian youth.

\subsection{Financial Education (FE)}

FE is defined as any mode of FE that is delivered through any platform, such as in high schools, colleges, universities 
or workplaces (Xiao \& Porto, 2017). Potrich et al., (2016) defined $\mathrm{FE}$ as a development process that helps a person to make correct decisions and to manage his or her personal financial affairs effectively. The standard definition of FE used by the Organisation for Economic Co-operation and Development [OECD] (2016) says that it is the process by which financial consumers or investors improve their understanding on financial products, concepts and risks through information, and develop skills to make informed choices and to take other effective actions to improve their financial well-being. Lusardi and Mitchell (2014) conceptualised FE as an improvement process for individuals to better understand financial concepts through information, education and advice. In summary, FE is defined as any mode of FE programs, including courses, training, seminar, workshop or any education activities, delivered in various formal or informal platforms with the objectives to equip, enhance and educate individuals with sufficient financial knowledge, skills and tools in managing their own financial resources effectively.

The ultimate goal of FE is behavior change associated with improvement in individual knowledge skills and financial management, to enhance capability to manage risks and develop long-term financial plan (OECD, 2016). FE is about delivering knowledge. Meanwhile FL is more complex because it is about the acquisition and the application of knowledge (Potrich et al., 2016). FE is a predictor of individual FL (Atkinson \& Messy, 2013). Yoshino, Morgan, and Wignaraja (2015) considered FE as a substantial building process, which consequently results in improved individual FL. However, confusion arises when some scholars have used the term FE interchangeably with FL and financial capabilities (Fernandes, Lynch, \& Netemeyer, 2014). FE is expected to build up the foundation of financial knowledge regarding saving, credit, budgeting, investment, debt management, wealth accumulation that are synonymous with daily financial life (OECD, 2016). Knowledge and information acquisition gained from $\mathrm{FE}$ can assist individuals to understand financial concept better, make them more skilful in managing money and enhance individual literacy level associated with right financial decisions.

FA can be shaped through the intervention of FE because FE domains can align attitude with behavior and has a synergistic effect on behavior outcomes (Fong \& Khoo, 2015). $\mathrm{FE}$ also tends to influence the differences on knowledge and skills between individuals with positive attitude and those with negative attitude (Fong \& Khoo, 2015; Suki \& Suki, 2017). The inclusion of attitudinal components in FE such as credit management, cash management, saving and budgeting will benefit the participants to inculcate positive FA, restore trust and confidence. This may also prevent risky financial behaviors and poor financial practices such as overspending or compulsive buying (Batty, Collins, \& Odders-White, 2014). The enrolment in FE courses will motivate youth to apply skills knowledge learned in order to make effective financial decision across various financial fields. Given the close relationship between FA and cognitive and behavioral competence, by enforcing the correct financial norms and standards through FE, the process of developing healthy financial behaviors and promoting financial well-being can be achieved. The literature review conducted by Amagir, Groot, Brink, and Wilschut (2017) has shown that formal FE has positive effects on financial development or better known as the socialization process. Similarly, studies conducted in Brazil by Bruhn, Leão, Legovini, Marchetti, and Zia (2016) found that FE has positive effect on FA and behaviors among respondents. FE also leads to awareness of the consequences of socio-economic development of society, particularly with regard to prevention of over-indebtedness. Higher assumption that enrolment in FE benefits individuals in understanding financial concepts, budgeting, avoidance from compulsive buying or spending decisions, and developing more positive FA and further engaged with PFMP. Ultimately, the FE contributes to the development of the country's economy, society as a whole and also social sustainable.

Parents with sound financial knowledge will be able to transmit their knowledge to their children through communication, teaching, mentoring, modeling of financial concepts or positive financial behavior (Akben-Selcuk, 2015). Increase in FE will improve children's skills and in turn will improve their financial behavior (Finders, Diaz, Geldhof, Seknan, \& Rennekamp, 2016). Through FE, youth will be equipped with the required skills and practices that can be transmitted in the short term or during the development of the outcomes. The relationship between children and parents will inculcate positive parenting practices, and this will help the children's healthy brain development. Consequently, the children's social and cognitive skills will be improved. The introduction of FE especially through formal education platform considered as effective strategies to increased financial knowledge among youth and to the parents itself. Parents are an important source of informal socialization agents, and higher FE among parents has shown to be correlated with higher FL among young people (Bowen, 2002; Mandell, 2008). FL has also been shown to be positively associated with parental income (Mandell, 2008). Kiliyani and Sivaram (2016) indicate that gender, marital status, age, religion, education, discipline to study, occupation, work experience, income, and parents' education background influence FL level. The literature emphasizes that mandatory FE is able to motivate self-control that relates to financial practices and prudent financial behaviors (Kaiser \& Menkhoff, 2016). FE programs targeting the youth is a very effective strategy not only for conveying financial knowledge, but also for improving financial skills 
as measured by changes in financial behavior and related preferences and personality traits. The findings proved that strengthening the case for investing in FE of the young is as an antidote to widespread financial illiteracy.

Several studies have established with strong evidence that FE affects the relationship between FL and PFMP (Brugiavini, Cvapozzi, Padula, \& Pettinicchi, 2015; Hasting, Madrian, \& Skimmyhorn, 2012). The FL level can determine whether or not an individual has received or participated in any FE courses during his or her lifetime (Luksander, et al., 2014). A recent study by Kiliyanni and Sivaraman (2016) showed that high FL is more recognised importance in FE compared with those having lower literacy level. Financial knowledge and skills gained and learned from FE irrespective of the training courses or any activities attended can be applied, can guide and can assist youth to make the right financial decisions. Thus, it can boost the confidence level when they deal with financial transactions and may directly avoid any financial errors (Scheresberg, 2013). Therefore, FE can be considered as a key dimension to enhance youth FL although others dimension should be considered too. FL has to inculcate at early live specifically during time as a student so that young people are able to develop skills and knowledge required to successfully manage their financial especially after graduated and earning their own money.

Additionally, during this period of time, young people starting to learn money management independently required a lot of financial money transaction and prompt financial decision. Therefore, it is essential to expose the young age group with right and sufficient FE programs to enhance their FL level. Although there is various strategies used in providing or integrating FE into the curriculum or education system, the objective remained unchanged, which is to increase the literacy level. Brown et al., (2018) mentioned that exposure to $\mathrm{FE}$ helped improved youth financial decision-making. Clearly, FE can play an important role in enhancing FL among young people, helping them managing their financial resources effectively, learn to save and avoid any unnecessary spending behavior or accrue debt. Thus, the hypotheses postulate on moderator roles of FE with FA, PFS and FL with PFMP as follows;

$\mathbf{H}_{4}$ : When the perceived usefulness of Financial Education (FE) is higher, the relationship between Financial Attitude (FA) is higher and the tendency to practise Prudent Financial Management Practices (PFMP) is stronger.

$\mathbf{H}_{5}$ : When the perceived usefulness of Financial Education (FE) is higher, the relationship between Parental Socialisation (FS) and the tendency to practise Prudent Financial Management Practices (PFMP) is stronger.

$\mathbf{H}_{6}$ : When the perceived usefulness of Financial Education (FE) is higher, the relationship between Financial
Literacy (FL) and the tendency to practise Prudent Financial Management Practices (PFMP) is stronger.

\subsection{Theory Planned Behavior (TPB)}

TPB posits three determinants of intention that indirectly apply the effect on behavior intention (Ajzen, 1991). According to TPB, behavioral belief refers to attitude as a predictor towards favorable or unfavorable attitudes. Any financial practice, whether negative or positive, carries a significant relationship and has substantial influence towards individual financial management practices. Based on discussions in previous studies, in this study, all the three TPB variables, namely, attitude, subjective norms and perceived behavioral control are expected to have a link in predicting behavior intention of youth towards PFMP. The higher the level of favorable attitude (FA), subjective norms (PFS) and perceived behavioral control towards the behavior (FL), the stronger will be the intention of young people to consider employing the PFMP. The theoretical framework for this study is as follow (see Figure 1):

\section{Research Methodology}

In this study, the quantitative method using a questionnaire will be employed for collecting data to be analysed. In this study, the targeted respondents are Malaysian youth within the age of 18 to 30, who are currently studying at the selected institutions of higher learning (IHLs) in Malaysia and have completed the FE subject in Personal Financial Management (PFM). Students falling within youth demographics were selected because evidence has shown that this group is in a stage of experimenting money management skills, in which they are required to make many financial decisions independently, at the same time experiencing financial problems (Sachitra, Wijesinghe, \& Gunasena, 2019). The questionnaire has been designed based on previous studies, and has been considered as having acceptable reliability and related to relevant studies, as explained in the conceptual framework. The questionnaire contained 41 items, including questions for screenings (two items), demographics (eight items), FA (eight items), PFS (four items), FL (four items), FE (five items) and PFMP (10 items).

All the questions were divided into six sections from Section A to Section F. FA was measured by eight statements taken from the study by Potrich, Viera, Coronel, and Filho (2015) which examined the financial attitude in Southern Brazil: Modeling and invariance between genders whereby the questions adopted in the study focused at the component of the financial attitude of the respondents. PFS was measured through four statements in the questionnaire and was adopted from the study by Shim et al., (2009). Their study focused at the financial socialization, the role of 


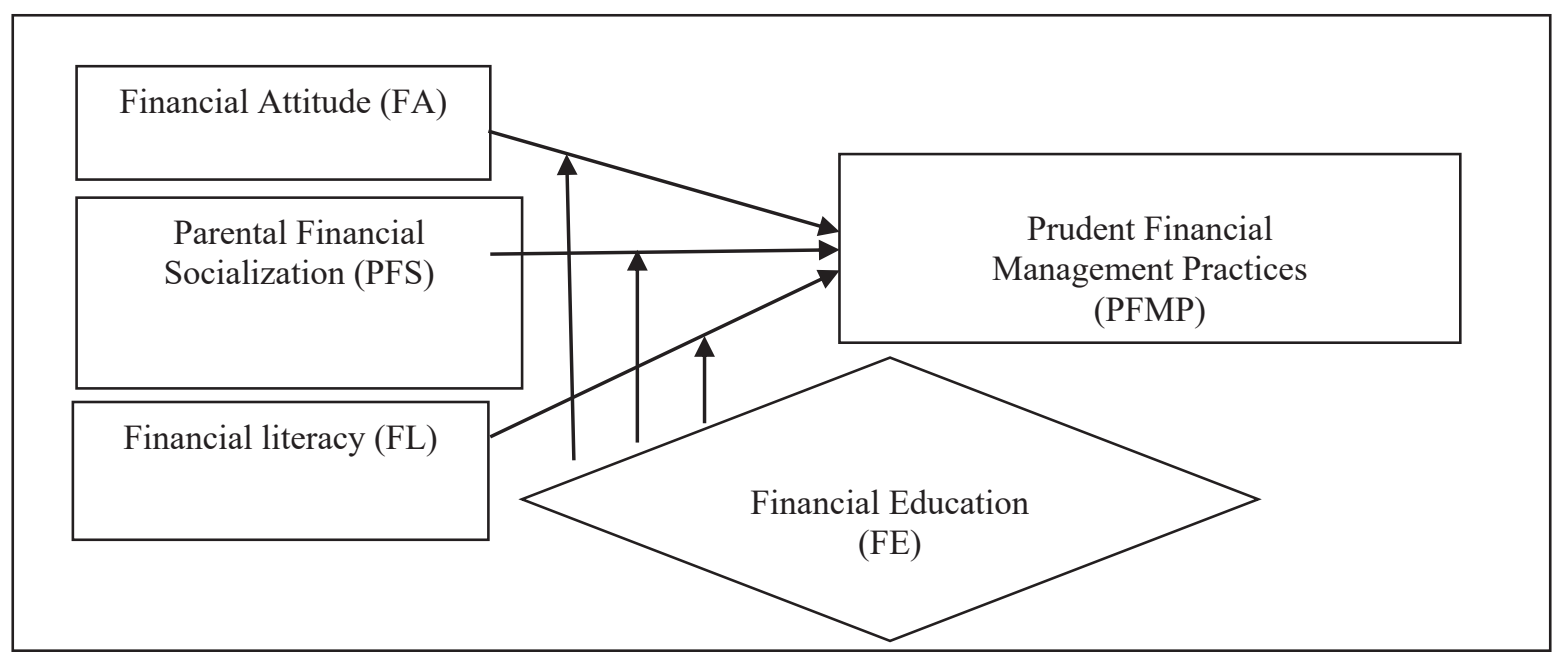

Figure 1: The conceptual framework

family, work, and education. FL was adopted from the study by Hira and Loibl (2005), which looked at understanding the impact of provided FE on the workplace satisfaction and represented with four statements in the questionnaire. Meanwhile FE was represented by five statements in the questionnaire and was adopted from the study by Perry and Morris (2005), which investigated the role of self-perception, knowledge, and income in explaining consumer financial behavior. Finally, the ten statements to represent PFMP were adopted from Joo and Grable (2004), which conducted a study on exploratory framework of the determinants of financial satisfaction. All of these variables were measured based on a five-point Likert scale (1 for "strongly disagree" to 5 for "strongly agree).

\section{Results}

In this study, data are analysed using Partial Least Squares Structural Equation Model (PLS-SEM). The analysis is divided into two sub-models, namely, the measurement model (outer model) and the structural model (inner model). An assessment of measurement models has produced reliability and validity values for each indicator and constructs used in this study. The result showed that the composite reliability (CR) values for all constructs is between 0.832 and 0.931 . $\mathrm{CR}$ values showed that all the constructs had high level of internal consistency and high reliability (Hair, Hult, Ringle, $\&$ Sarsted, 2017). After going through the measurement model analysis, the measurement results obtained from this assessment are summarized in Table 1.

Once validity and reliability are achieved, the next step involves an assessment of the structural models. The assessment required to explain that the model is significant and can solve the questions as hypothesised in the study. Assessment of significance relationship between the hypothesised constructs can be done through path coefficient $(\beta)$. To get the value $(\beta)$, the bootstrapping technique is applied. In this study, 5000 subsamples were used, as recommended by Hair et al., (2017). The result from the bootstrapping method gave three values, namely path coefficient $(\beta), t$ and $p$ values. The values of $t$ and $\mathrm{p}$ are the values that are referred when determining the reliability of the hypotheses that have been formulated whether they should be accepted or rejected. To determine the significance of the $\beta$ value, the standard error calculated from bootstrapping procedure would provide a $t$ value.

For this study, a confidence level of $95 \%$ was used and the value of $t=1.645$ was the relevant $t$ value of reference. Any $t$ value higher than 1.645 indicates that the relationship between the constructs is significant at the $95 \%$ confidence level, and the hypothesis for the relationship between the constructs is supported. This structural model will be used to answer research hypothesis for $\mathrm{H} 1, \mathrm{H} 2$ and $\mathrm{H} 3$. For moderator analysis, an assessment of the significance of moderator relationship is required to analyse the interaction of $\mathrm{FE}$ as moderator interacting of the exogenous construct FA, PFS and FL with the endogenous construct, PFMP. The strength of the relationship between the exogenous and the endogenous variables may increase or decrease depending on the moderator interaction. Table 2 present results analysis for all hypothesis of the study.

Results of the analysis showed that all the exogenous constructs, FA, PFS and FL had significant positive relationship with the endogenous variable, PFMP. Results for hypothesis testing of $\mathrm{H}_{1}$ showed that $\mathrm{FA}$ was significantly and positively related to PFMP $(\beta=0.198, \mathrm{p}<0.05)$, thus 
Table 1: Results for Measurement Model Analysis

\begin{tabular}{|c|c|c|c|c|c|c|}
\hline \multirow{2}{*}{ Indicators } & \multirow{2}{*}{$\begin{array}{l}\text { Indicator } \\
\text { reliability }\end{array}$} & \multirow{2}{*}{$\begin{array}{c}\begin{array}{c}\text { Internal } \\
\text { consistency } \\
\text { reliability }\end{array} \\
\text { AVE }\end{array}$} & \multirow{2}{*}{$\begin{array}{c}\begin{array}{c}\text { Convergent } \\
\text { validity }\end{array} \\
\text { CR }\end{array}$} & \multicolumn{3}{|c|}{ Discriminant validity } \\
\hline & & & & $\begin{array}{l}\text { Cross } \\
\text { Loading }\end{array}$ & $\begin{array}{c}\text { Fornell } \\
\text { Lacker's }\end{array}$ & HTMT \\
\hline FA1 & 0.752 & \multirow{7}{*}{0.536} & \multirow{7}{*}{0.889} & 0.752 & \multirow{7}{*}{0.732} & \multirow{7}{*}{$<0.90$} \\
\hline FA2 & 0.816 & & & 0.816 & & \\
\hline FA3 & 0.75 & & & 0.750 & & \\
\hline FA4 & 0.763 & & & 0.763 & & \\
\hline FA5 & 0.689 & & & 0.689 & & \\
\hline FA6 & 0.706 & & & 0.706 & & \\
\hline FA7 & 0.634 & & & 0.634 & & \\
\hline PFS1 & 0.717 & \multirow{4}{*}{0.629} & \multirow{4}{*}{0.871} & 0.717 & \multirow{4}{*}{0.820} & \multirow{4}{*}{$<0.90$} \\
\hline PFS2 & 0.857 & & & 0.857 & & \\
\hline PFS3 & 0.796 & & & 0.796 & & \\
\hline PFS4 & 0.797 & & & 0.797 & & \\
\hline FL1 & 0.833 & \multirow{4}{*}{0.773} & \multirow{4}{*}{0.931} & 0.833 & \multirow{4}{*}{0.879} & \multirow{4}{*}{$<0.90$} \\
\hline FL2 & 0.883 & & & 0.883 & & \\
\hline FL3 & 0.897 & & & 0.897 & & \\
\hline FL4 & 0.901 & & & 0.901 & & \\
\hline FE1 & 0.796 & \multirow{5}{*}{0.672} & \multirow{5}{*}{0.911} & 0.796 & \multirow{5}{*}{0.710} & \multirow{5}{*}{$<0.90$} \\
\hline FE2 & 0.784 & & & 0.784 & & \\
\hline FE3 & 0.868 & & & 0.868 & & \\
\hline FE4 & 0.819 & & & 0.819 & & \\
\hline FE5 & 0.83 & & & 0.830 & & \\
\hline PFMP1 & 0.825 & \multirow{5}{*}{0.504} & \multirow{5}{*}{0.832} & 0.825 & \multirow{5}{*}{0.793} & \multirow{5}{*}{$<0.90$} \\
\hline PFMP2 & 0.795 & & & 0.795 & & \\
\hline PFMP3 & 0.764 & & & 0.764 & & \\
\hline PFMP4 & 0.565 & & & 0.565 & & \\
\hline PFMP5 & 0.55 & & & 0.550 & & \\
\hline
\end{tabular}

Table 2: Summary of Structural Results

\begin{tabular}{|l|l|c|c|c|c|c|}
\hline & Relationship & Std. $\boldsymbol{B}$ & SE & t value & p value & Result \\
\hline H1 & FA -> PFMP & 0.198 & 0.051 & 3.843 & 0.000 & Supported \\
\hline H2 & PFS -> PFMP & 0.170 & 0.058 & 2.906 & 0.002 & Supported \\
\hline H3 & FL -> PFMP & 0.251 & 0.054 & 4.614 & 0.000 & Supported \\
\hline H4 & FA -> FE -> PFMP & 0.054 & 0.055 & 0.973 & 0.165 & Not supported \\
\hline H5 & PFS-> FE -> PFMP & 0.016 & 0.056 & 0.293 & 0.385 & Not supported \\
\hline H6 & FL-> FE -> PFMP & 0.020 & 0.056 & 0.331 & 0.370 & Not supported \\
\hline
\end{tabular}


$\mathrm{H}_{1}$ was supported. For hypothesis $\mathrm{H}_{2}$, PFS was found to be significant and positively related to PFMP $(\beta=0.170, \mathrm{p}<$ 0.05 ), thereby $\mathrm{H}_{2}$ was also supported. Similarly, for $\mathrm{H} 3$, results showed that FL had a significant and positive relationship with PFMP $(\beta=0.251, \mathrm{p}<0.05)$. This showed that FL had the most significant impact on PFMP, followed by FA and PFS with $t$ values 4.614, 3.843 and 2.906, respectively. For the moderating interaction, the results showed that FE did not moderate the relationship between FA, PFS, and FL on PFMP. For hypothesis $\mathrm{H}_{4}$ the results showed that $\mathrm{FE}$ did not moderate the relationship between FA and PFMP ( $\beta=$ $0.054, p<0.05$ ). Similarly, for $\mathrm{H}_{5}, \mathrm{FE}$ did not moderate the relationship between PFS and PFMP $(\beta=0.016, p<0.05)$, thus, $\mathrm{H}_{5}$ was also not supported. Finally, for hypothesis $\mathrm{H}_{6}$, FE did not moderate the relationship between FL and PFMP $(\beta=0.020, p<0.05)$, thus, $\mathrm{H}_{6}$ was also not supported.

\section{Discussion}

PFMP is a lifetime objective of everyone and is the foundation for future financial well-being. The process begins at an early age of each individual and then further developed, continued and carried over the life course. The study provides evidence about the influence of mandated FE at colleges and universities as a way to improve young Malaysians' financial knowledge and increase their financial behaviors. Results of the study showed that FA, PFS and FL have positive significant effects on their financial behavior and financial practices, PFMP. However, the effort to introduce $\mathrm{FE}$ as an intervention to combat financial illiteracy showed that it has little impact and is ineffective towards FA, PFS and FL. The findings showed that FE did not significantly moderate the relationship between FA, PFS and FL and PFMP. This indicates that there are other factors or variables influencing their PFMP. The outcome of the study has also provided implications to certain bodies such as the government, the non-government sector and individuals. An explanation for why FE did not have a more significant impact when taught as a subject in FE courses, is that the time distance from learning the courses until the time they get to apply the concepts in practice is long.

Policymakers should also take into account the level of financial practices among young people to ensure they provide FE materials and courses that suit their level of knowledge, and that the material is useable and can be understood. All in all, the analysis conducted here provides interesting insights about the effectiveness of financial education for the youth. These are very promising findings that further underscore the benefits of fostering FE education among young Malaysians. Evaluating the distributional effects of financial education interventions is key to providing information on the design and tailoring the interventions to suit youth level of understanding. These estimates will allow us to ensure whether the average impact estimated is driven towards a segment of the beneficiaries, to identify the trajectory of initial inequalities and monitor the gap across groups, and to infer whether the intervention will work with a different group segmentations or target groups.

The study proved that FA, PSF and FL significantly predicted youth financial behaviors. At the same time, the strong relationship showed that the important of FA, PFS and FL in determining youth's financial behavior. It is important for young people to possess positive FA because what they feel, perceive and believe may influence the likelihood for them to transform into actual behavior. As the closest role model and primary socialisation agent, parents should be aware of the roles they play and their involvement in transferring financial knowledge and skills that could shape financial behavior of their children.

Regarding the variables, this study revealed that FL is the most significant predictor of PFMP. It is evident that possessing higher level of FL could cause young people to prompt financial decisions associated with prudent financial behavior. The effort to introduce and promote $\mathrm{FE}$ as an intervention tool did not show positive result to improve financial behavior and outcomes. Even though, many expected that $\mathrm{FE}$ is the best intervention tool to improve financial illiteracy, the result of the study showed contradictory evidence to the findings of previous studies. FE within the context of Malaysia's education system may not be effective and short on the quality to improve financial behavior of the youth. Thus, the results can assist respective stakeholders such as policy-makers, educators, and financial institutions to use the findings to re-evaluate the programs' effectiveness and look into the programs' shortcomings. It is important that all $\mathrm{FE}$ contents cover the elements and concepts applicable and related to the real financial life of young Malaysians.

Future studies should consider examining the content of FE syllabus and components, policies, strategies, and types of professional development strategies for educators for implementation. The effects of financial education, $\mathrm{FE}$, depend on whether they are taught during primary or secondary education. Consideration should be given to potential changes brought about by FE in the context of the Malaysian scenario in enhancing financial inclusion and improved financial well-being, specifically among the young age groups. Such studies could enrich the knowledge and assist respective countries stakeholders to generate more effective initiatives and efforts towards making the future generation will apply prudent financial practices. 


\section{References}

Aguirre-Bielschowsky, I., Lawson, R., Stephenson, J., \& Todd, S. (2018). Kids and kilowatts: Socialization, energy efficiency, and electricity consumption in New Zealand. Energy Research \& Social Science, 44, 178-186.

Ajzen, I. (1991). The theory of planned behavior. Organizational Behavior and Human Decision Processes, 50, 179-211.

Akben-Selcuk, E. (2015). Factors influencing college students' financial behavior in Turkey: Evidence from a national survey. International Journal of Economics and Finance, 7(6), 87-94.

Amagir, A., Groot, W., Brink, H. M.V.D., \& Wilschut, A. (2017). A review of financial-literacy education programs for children and adolescents. Citizenship, Social \& Economics Education, 17(1), 56-80. https://doi.org/10.1177/2047173417719555

Atkinson, A., \& Messy, F.A. (2013). Promoting financial inclusion through financial education. OECD/INFE evidence, policies and practices; OECD Working Papers on Working Papers on Finance, Insurance and Private Pensions. OECD.

Aydin, A. E., \& Akben S. E. (2019). An investigation of financial literacy, money ethics and time preferences among college students. International Journal of Bank Marketing, 37(3), 880890.

Batty, M., Collins, M., \& Odders-White, E. (2014). Experimental evidence on the effects of financial education on elementary schools students' knowledge, behavior and attitudes. The Journal of Consumer Affairs, 49(10), 69-96.

Bowen, C. F. (2002). Financial knowledge of teens and their parents. Financial Counseling and Planning, 13(2), 93-102.

Brown, M., Henchoz, C., \& Spycher, T. (2018). Culture and financial literacy: Evidence from a within-country language border. Journal of Economic Behavior \& Organization, 150, 62-85.

Brugiavini, A., Cavapozzi, D., Padula, M., \& Pettinicchi, Y. (2015). Financial education, literacy and investment attitudes. SAFE Working Paper Series 86, Research Center SAFE - Sustainable Architecture for Finance in Europe, Goethe University Frankfurt doi:10.2139/ssrn.2637878

Bruhn, M., Leão, L. S., Legovini, A., Marchetti, R., \& Zia, B. (2016). The impact of high school financial education: Evidence from a large-scale evaluation in Brazil. Applied Economics, 8(4), 256-295.

Chowa, G. A. N., \& Despard, M. R. (2014). The influence of parental socialization on youth financial behavior: Evidence from Ghana. Journal of Family and Economic Issues, 35(3), 376-389.

Davis, K., \& Hustvedt, G. (2012). It's a matter of control: Saving for retirement. International Review of Social Sciences and Humanities, 3(2), 248-261.

Demirguc-Kunt, A, Klapper, L.,Singer, D., Ansar, S., \& Hess, J. R. (2018). The global database 2017: Measuring financial inclusion and fintech revolution (English). Washington:
World Bank Group. Retrieved March 10, 2020 from: http:// Documents.worldbank.org/ curated/en/332881 52587 3182837/ The-Global-Findex-Database-2017-Measuring-FinancialInclusion-and-the-Fintech Revolution

Eagly, A. H., \& Chaiken, S. (2007). The advantages of an inclusive definition of attitude. Social Cognition, 25(5), 582-602.

Falahati, L., \& Paim, L. (2012). Experiencing financial problems among university students. Gender in Management, 27(5), 315-330.

Fan, L., \& Chatterjee, S. (2019). Financial socialization, financial education, and student loan debt. Journal of Family and Economic Issues, 40(1), 74-85.

Fernandes, D., Lynch, J. G. Jr., \& Netemeyer, R. G. (2014). Financial literacy, financial education, and downstream financial behaviors. Management Science, 60(8), 1861-1883.

Finders, J. K., Diaz, G., Geldhof, G. H., Sektnan, M., \& Rennekamp, D. (2016). The impact of parenting education on parent and child behaviors: Moderators by income and ethnicity. Children and Youth Services Review, 71, 199-209.

Fong, K. Y., \& Khoo, C. H. (2015). Attitude, learning environment and current knowledge enhancement of accounting students in Malaysia. Journal of Accounting in Emerging Economic, 5(2), 202-221.

Fornell, C., \& Larcker, D.F. (1981) Evaluating structural equation models with unobservable variables and measurement error. Journal of Marketing Research, 18(1), 39-50

Grohmann, A., Kouwenberg, R., \& Menkhoff, L. (2015). Childhood roots of financial literacy. Journal of Economic Psychology, 51, 114-133.

Gudmunson, C. G., \& Danes, S. M. (2011). Family financial socialization: Theory and critical review. Journal of Family and Economic Issues, 32(4), 644-667.

Guzman, F., Paswan, A., \& Tripathy, N. (2019). Consumer centric antecedents to personal financial planning. Journal of Consumer Marketing, 36(6), 858-868.

Hair, J. F., Hult, T. M., Ringle, C. M., \& Sarsted, M. (2017). A primer on partial least squares structural equation modelling (PLS-SEM) (2nd ed.). Thousand Oaks, CA: Sage.

Hira, T. K., \& Loibl, C. (2005). Understanding the impact of employer-provided financial education on the workplace satisfaction. The Journal of Consumer Affairs, 39(1), 173-194.

Hastings, J. S., Madrian, B. C., \& Skimmyhorn, W. L.2013). Financial literacy, financial education and economic outcomes. Annual Review of Economic, 5(1), 347-373.

Ibrahim, M. E., \& Alqaydi, F. R. (2013). Financial literacy, personal financial attitude and forms of personal debt among resident of UAE. International Journal of Economic and Finance, 5(7), 126-138.

Joo, S., \& Grable, J. E. (2004). An exploratory framework of the determinants of financial satisfaction. Journal of Family and Economic Issues, 25(1), 162-171. 
Jung, M.H. (2019). A structural analysis on the influence of multicultural families in psychological inadequacy for youth. Journal of Asian Finance, Economics and Business, 6 (2), 239-246.

Luksander, A., Béres, D., Huzdik, K., \& Németh, E. (2014). Analysis of the factors that influence the financial literacy of young people studying in higher education. Public Finance Quarterly, 2, 221-241.

Lusardi, A., \& Mitchell, O. S. (2014).The economic importance of financial literacy: Theory and evidence. Journal of Economic Literature, 52(1), 5-44.

Kagotho, N., Nabunya, P., Ssewamala, F., Mwangi, E. N., \& Njenga, G. (2017). The role of family financial socialization and management skills on youth saving behavior. Journal of Adolescence. 57,134-138.

Kaiser, T., \& Menkhoff, L. (2016). Does financial education impact financial literacy and financial behavior, and if so, when? Discussion papers, 1562. Available at: http://www.diw.de/ documents/publikationen/73/diw_01.c.529454.de/dp1562.pdf

Kaplan, M. S., Huguet, N., Caetano, R., Giesbrecht, N., Kerr, W. C., \& McFarland, B. H. (2015). Economic contraction, alcohol intoxication and suicide: Analysis of the national violent death reporting system. Injury Prevention, 21(1), 35-41.

Kiliyanni, A. K., \& Sivaraman, S. (2016). The perception-reality gap in financial literacy: Evidence from the most literate state in India. International Review of Economic Education, 3, 47-64.

Mandell, L. (2008). Financial literacy of high school students. In Xioa, Jing Jian (Ed.) Handbook of consumer finance research. New York: Springer, pp163-183.

Messacar, D., \& Frenette, M. (2019). Education savings plans, matching contributions, and household financial allocations: Evidence from a Canadian reform. Economics of Education Review, 73, 101922. Doi:/10.1016/j.econedurev .2019.101922

Mette, F. M. B., deMatos, C. A., Rohden, S. F., \& Ponchio, M. C. (2018). Explanatory mechanisms of the decision to buy on credit: The role of materialism, impulsivity and financial knowledge. Journal of Behavioral and Experimental Finance, $21,15-21$.

Mihalčová, B., Csikósová, A., \& Antošová, M. (2014). Financial literacy - The urgent need today. Procedia -Social and Behavioral Sciences. 109, 317-321.

Mikeska, J., Harrison, L.R., \& Carlson, L. (2017). A meta-analysis of parental style and consumer socialization of children. Journal of Consumer Psychology, 27(2), 245-256.

Organisation for Economic Co-operation and Development (2016). Financial education in Europe. Trend and recent development. Paris: OECD. http://dxdoi.org/ 10.1787.9789264254855-en

Paluri, R. A., \& Mehra, S. (2016). Financial attitude based segmentation of women in India. An exploratory study. Journal of Bank Marketing, 34(5), 670-689.
Perry, V. G., \& Morris, M. D. (2005). Who is in control? The role of self-perception, knowledge, and income in explaining consumer financial behavior. Journal of Consumer Affairs, 39(2), 299-313.

Potrich, A. C. G., Viera, K. M., \& Mendes-Da-Silva, W. (2016). Development of a financial literacy model for university students. Management Research Review, 39(3), 356-376.

Potrich, A. C. G., Viera, K. M., Coronel, D. A., \& Filho, R. B. (2015). Financial literacy in Southern Brazil: Modeling and invariance between genders. Journal of Behavioral and Experimental Finance, 6, 1-12.

Ramalho, T. B., \& Forte, D. (2018). Financial literacy in Brazil - Do knowledge and self-confidence relate with behavior? RAUSP Management Journal, 54(1), 77-95.

Sachitra, V., Wijesinghe, D., \& Gunasena, W. (2019). Exploring undergraduates' money-management life: Insight from an emerging economy. Young Consumers, 20(3), 167-189.

Shim, S., Barber, B. L., Card, N. A., Xiao, J. J., \& Serido, J. (2009). Financial socialization of first-year college students: The roles of parents, work, and education. Journal of Youth and Adolescence, 39(12), 1457-1470.

Scheresberg, C. D. B. (2013). Financial literacy and financial behavior among young adults: Evidence and implication. Numeracy, 6(2), 1-21.

Shockey, S. S. (2002). Low-wealth adult's financial literacy: Money management behavior and associates factors, including critical thinking. (Unpublished doctoral dissertation, The Ohio State University, AAT 3039524).

Skagerlund, K., Lind, T., Strömbäck, C., Tinghög, G., \& Västfjäll, D. (2018). Financial literacy and the role of numeracy-How individuals' attitude and affinity with numbers influence financial literacy. Journal of Behavioral and Experimental Economics, 74, 18-25

Suki, N.M., \& Suki, N.M. (2017). Modeling the determinants of consumers' attitudes toward online group buying: Do risks and trusts matters? Journal of Retailing and Consumer Services, 36,180-188.

Tham, K. W., Dastane, O., Johari, Z., \& Ismail, N. B. (2019). Perceived risk factors affecting consumers' online shopping behaviour. Journal of Asian Finance, Economics and Business, 6(4), 246-260. https://doi.org/10.13106/jafeb.2019.vol6. no4.249

Titman, S. J., Keown, A. J., \& Martin, J. H. (2017). Financial Management (13th ed.). Harlow, UK: Pearson.

Tsui-Yii, S., \& Shen-Chen K. (2014). Determinates of financial behavior: Insight into consumer money attitudes and financial literacy. Services Business, 8(2) 217-238.

Wang, J., \& Li, J. (2015) Precautionary Effort: Another trait for prudence. Journal of Risk and Insurance, 82(4), 977-983.

Webley, P., \& Nyhus, E.K. (2013) Economic socialization, saving and assets in European young adults. Economics of Education Review, 33, 19-30. 
Xiao, J. J., \& Porto, N. (2017). Financial education and financial satisfaction: Financial literacy, behavior, and capability as mediators. International Journal of Bank Marketing, 35(5), 805-817.

Yoshino, N., Morgan, J.P. \& Wignaraja, G. (2015). Financial education in Asia. Assessment and recommendation. ADBI working paper series. Asian Development Bank Institute. doi:/10.2139/ssrn.2641681
Zahirovic-Herbert, V., Gibler, K. M., \& Chatterjee, S. (2016). Financial literacy, risky mortgages, and delinquency in the US during the financial crisis. International Journal of Housing Markets and Analysis, 9(2), 164-189.

Zulfaris, M.D., Mustafa, H., Mahussin, M., Alam, M. K., \& Daud, Z. M. (2020). Students and money management behavior of Malaysian public university. Journal of Asian Finance, Economics and Business, 7(3), 245-252. https://doi. org/10.13106/jafeb.2020.vol7.no3.245 